\title{
Molecular identification of Trichogramma species from South and South-East Asia and natural Wolbachia infection
}

\author{
Yu-Di Liu, Mao-Lin Hou \& Kai Song
}

\begin{abstract}
Liu, Y.-D., Hou, M.-L. \& Song, K. 2017: Molecular identification of Trichogramma species from South and South-East Asia and natural Wolbachia infection. - Entomol. Fennica 28: 57-66.

Trichogramma wasps were collected from the parasitized eggs of lepidopteran pests from 21 sampling sites in East Asia and South-East Asia. Six Trichogramma species were identified based on the molecular identification method using the internal transcribed spacer 2 (ITS2) region of the rDNA of Trichogramma chilonis, T. evanescens, T. ostriniae, T. embryophagum, T. dendrolimi and $T$. japonicum. The results of molecular identification were confirmed by morphological identification. Additionally, natural populations were screened for the prevalence of Wolbachia. Five out of 21 populations were infected by the same Wolbachia strain, which was identified by using Wolbachia wsp gene and multilocus sequencing approach. The phylogenetic analysis of Wolbachia wsp sequences revealed that the Wolbachia strain was classified in the strain wEvaA in the group of EvA of the supergroup A.
\end{abstract}

Y.-D. Liu* \& M.-L. Hou, State Key Laboratory for Biology of Plant Diseases and Insect Pests, Institute of Plant Protection, Chinese Academy of Agricultural Sciences, No. 2, West Yuan Ming Yuan Road, Beijing 100193, China; *Corresponding author'se-mail: ydliu@ippcaas.cn

K. Song, Dryland Farming Institute, Hebei Academy of Agricultural and Forestry Sciences, Hengshui, China

Received 15 December 2015, accepted 11 November 2016

\section{Introduction}

There are about 650 species in the family Trichogrammatidae (Grissel \& Schauff 1990), and they are the most widely used parasitoids in biological control programs (Kumar et al. 2009). For successful biological control purpose, the identification of Trichogramma species is the important first step (Hassan 1994). Unfortunately, species identification in this group is difficult due to their small size, the large number of species, and the lack of clear morphological characteristics. Identification is time consuming and requires special- ized skills (Pinto et al. 1989, Pinto \& Stouthamer 1994, Poorjavad et al. 2012). In order to be of economic importance in biological control projects, it is essential to be able to identify the Trichogrammatid species quickly, and the methods have to be simple and widely applicable.

Molecular approaches based on DNA sequences of the internal transcribed spacer 2 (ITS2) have helped to solve the above difficulty (Stouthamer et al. 1999). Several studies have used the ITS region to identify the Trichogramma species occurring in different regions (Silva et al. 1999, Kumar et al. 2009, Sumer et al. 2009, 
Poorjavad et al. 2012, Nasir et al. 2013, Pino et al. 2013). The ITS2 region has been used to distinguish Trichogramma species collected from tomato fields in Portugal by sequencing and restriction analysis (Silva et al. 1999). Pino et al. (2013) rapidly identified five Trichogramma species occurring in the Canary Islands by using multiplex PCR method based on amplification of ITS2 region. Poorjavad et al. (2012) used PCR amplification of ITS2 region to identify seven Iranian Trichogramma species, which were identical in external morphology. Nasir et al. (2013) used the ITS2 region of rDNA to distinguish six Trichogramma species collected from different ecological zones of Pakistan.

In East Asia and South-East Asia, rice (Oryza sativa L.) is a staple food source for more than half of the world's population (Gross \& Zhao 2014). To reduce the application of pesticides in control of the rice pests, integrated pest management (IPM) based on biological control by Trichogramma releases was launched (Ko et al. 2014). Therefore, in this study, comprehensive field surveys were conducted in these regions to collect Trichogramma species. Finally, Trichogramma were collected from 21 sampling sites in East Asia and South-East Asia. The molecular method based on ITS2 region was used to identify these Trichogramma species.

On the other hand, Wolbachia, as a symbiotic bacterium, plays important roles in evolution, ecology, and reproduction of their hosts (Werren 1997). They are extremely common, with 20 $76 \%$ of insect species being infected (Harris et al. 2003). More than 20 Trichogramma species have been partly or completely infected by Wolbachia (Poorjavad et al. 2012). Because Wolbachia infection can affect the wasp's fitness, it is necessary to investigate the infection status of a population, which may give important aids for Trichogramma application in biological control programs (Stouthamer \& Kazmer 1994, Horjus \& Stouthamer 1995, Poorjavad et al. 2012). Therefore, in this study, the collected Trichogramma wasps were screened for the infection with Wolbachia, and the respective Wolbachia strain was identified by sequences of Wolbachia surface protein (wsp), Cytochrome $c$ oxidase, subunit I $(\operatorname{cox} \mathrm{A})$ and Fructose-bisphosphate aldolase $(f b p \mathrm{~A})$.

\section{Materials and methods}

\subsection{Trichogramma collection}

Parasitized Trichogramma eggs were collected from 21 paddy fields in China and Korea in 2011 and 2012 (Table 1), and kept individually in glass tubes until adult emergence. In some fields, fresh sentinel eggs of Corcyra cephalonica (Stainton) (Lepidoptera: Pyralidae) were used to trap Trichogramma. Therefore, the originating host of Trichogramma for some sites is the sentinel host C. cephalonica. After collection, the adults were reared on eggs of the grain moth, Sitotroga cerealella Olivier (Lepidoptera: Gelenchiidae), in climate chambers at $25 \pm 1{ }^{\circ} \mathrm{C}, 70 \pm 5 \% \mathrm{RH}$ with the photoperiod of 14:10 (L:D) h. Populations are defined as the progeny from one egg batch, which are collected from the same species at the same location on the same day.

\subsection{DNA isolation}

DNA was extracted using chelating agent Chelex-100 (5\%) (Biorad) method according to Stouthamer et al. (1999). One to three wasps from the single parasitized egg were ground in $100 \mu \mathrm{l}$ 5\% Chelex-100 (Biorad) and $3 \mu 1$ proteinase $\mathrm{K}$ $(20 \mathrm{mg} / \mathrm{ml})$ and incubated for $2 \mathrm{~h}$ at $56{ }^{\circ} \mathrm{C}$, followed by $10 \mathrm{~min}$ at $95^{\circ} \mathrm{C}$. The supernatant was stored at $-20{ }^{\circ} \mathrm{C}$ for subsequent molecular analysis.

\subsection{PCR amplification}

The ITS2 region was amplified using the following primers: forward, 5-TGTGAACTGCAGGACACATG-3, located in the 5.8S rDNA; and reverse, 5 -GTCTTGCCTGCTCTGAG-3, located in the 28S rDNA closer to the 3 end of the ITS2 (Stouthamer et al. 1999). Touchdown thermal cycling programs encompassing a $5^{\circ} \mathrm{C}$ span of annealing temperatures at $55-50{ }^{\circ} \mathrm{C}$ were performed for the amplification using a S1000 ${ }^{\mathrm{TM}}$ Thermal Cycler (Bio-Rad). After an initial denaturation at $94{ }^{\circ} \mathrm{C}$ for $4 \mathrm{~min}$, cycling parameters were 10 cycles of $95^{\circ} \mathrm{C}$ for $20 \mathrm{~s}$, highest annealing temperature (decreased $0.5{ }^{\circ} \mathrm{C}$ per cycle) for $30 \mathrm{~s}$, and $72^{\circ} \mathrm{C}$ for $30 \mathrm{~s}$; and 30 cycles of $95^{\circ} \mathrm{C}$ for $20 \mathrm{~s}$, lowest annealing temperature for $30 \mathrm{~s}$, and 
Table 1. Origins of Trichogramma species and strains with originating hosts, no. of base pairs in ITS2 (internal transcribed spacer 2 region of rDNA) sequences and GenBank accession numbers.

\begin{tabular}{|c|c|c|c|c|}
\hline $\begin{array}{l}\text { Sample no. } \\
\text { and Code }\end{array}$ & Species & Population & Host & $\begin{array}{l}\text { ITS2 and } \\
\text { Acc. no. }\end{array}$ \\
\hline 1. Tc-CJ & T. chilonis & $\begin{array}{l}\text { Cuijia, Xing'an, China } \\
34^{\circ} 55^{\prime} 46^{\prime \prime} \mathrm{N}, 109^{\circ} 37^{\prime} 51^{\prime \prime} \mathrm{E}\end{array}$ & Corcyra cephalonica & $\begin{array}{r}426 \\
\text { KR148947 }\end{array}$ \\
\hline 2. TC-WLP & T. chilonis & $\begin{array}{l}\text { Wulipai, Xing'an, China } \\
24^{\circ} 24^{\prime} 0^{\prime \prime} \mathrm{N}, 120^{\circ} 37^{\prime} 58^{\prime \prime} \mathrm{E}\end{array}$ & C. cephalonica & $\begin{array}{r}426 \\
\text { KR148947 }\end{array}$ \\
\hline 3. TC-Lo & T. chilonis & $\begin{array}{l}\text { Vientiane, Laos } \\
17^{\circ} 58^{\prime} 0^{\prime \prime} \mathrm{N}, 102^{\circ} 36^{\prime} 0^{\prime \prime} \mathrm{E}\end{array}$ & Chilo suppressalis & $\begin{array}{r}426 \\
\text { KR148948 }\end{array}$ \\
\hline 4. Tc-NB & T. chilonis & $\begin{array}{l}\text { Ningbo, China } \\
29^{\circ} 52^{\prime} 48^{\prime \prime} \mathrm{N}, 121^{\circ} 33^{\prime} 0^{\prime \prime} \mathrm{E}\end{array}$ & C. suppressalis & $\begin{array}{r}426 \\
\text { KR148948 }\end{array}$ \\
\hline 5. Tc-MM & T. chilonis & $\begin{array}{l}\text { Hmawbi, Myanmar } \\
17^{\circ} 5^{\prime} 0^{\prime \prime} \mathrm{N}, 95^{\circ} 57^{\prime} 0^{\prime \prime} \mathrm{E}\end{array}$ & Scirpophaga incertulas & $\begin{array}{r}426 \\
K R 148948\end{array}$ \\
\hline 6. Tc-TW & T. chilonis & $\begin{array}{l}\text { Taiwan, China } \\
25^{\circ} 3^{\prime} 0^{\prime \prime} \mathrm{N}, 121^{\circ} 31^{\prime} 0^{\prime \prime} \mathrm{E}\end{array}$ & C. suppressalis & $\begin{array}{r}426 \\
\text { KR148948 }\end{array}$ \\
\hline 7. Tc-HS & T. chilonis & $\begin{array}{l}\text { Hengshui, China } \\
37^{\circ} 32^{\prime} 14^{\prime \prime} \mathrm{N}, 115^{\circ} 28^{\prime} 59^{\prime \prime} \mathrm{E}\end{array}$ & C. suppressalis & $\begin{array}{r}426 \\
\text { KR148949 }\end{array}$ \\
\hline 8. Te-HS & T. evanescens & $\begin{array}{l}\text { Hengshui, China } \\
37^{\circ} 32^{\prime} 14^{\prime \prime} \mathrm{N}, 115^{\circ} 28^{\prime} 59^{\prime \prime} \mathrm{E}\end{array}$ & Ostrinia furnacalis & $\begin{array}{r}546 \\
\text { KR148950 }\end{array}$ \\
\hline 9. Te-BJ & T. evanescens & $\begin{array}{l}\text { Beijing, China } \\
39^{\circ} 54^{\prime} 27^{\prime \prime} \mathrm{N}, 116^{\circ} 23^{\prime} 17^{\prime \prime} \mathrm{E}\end{array}$ & C. cephalonica & $\begin{array}{r}546 \\
\text { KR148950 }\end{array}$ \\
\hline 10. Te-CQ & T. evanescens & $\begin{array}{l}\text { Chongqing, China } \\
29^{\circ} 10^{\prime} 47^{\prime \prime} \mathrm{N}, 106^{\circ} 9^{\prime} 36^{\prime \prime} \mathrm{E}\end{array}$ & C. cephalonica & $\begin{array}{r}546 \\
\text { KR148950 }\end{array}$ \\
\hline 11. Te- K1 & T. evanescens & $\begin{array}{l}\text { Korea } \\
37^{\circ} 28^{\prime} \mathrm{N}, 126^{\circ} 37^{\prime} \mathrm{E}\end{array}$ & O. furnacalis & $\begin{array}{r}546 \\
\text { KR148950 }\end{array}$ \\
\hline 12. Te- K2 & T. evanescens & $\begin{array}{l}\text { Korea } \\
37^{\circ} 28^{\prime} \mathrm{N}, 126^{\circ} 37^{\prime} \mathrm{E}\end{array}$ & O. furnacalis & $\begin{array}{r}546 \\
\text { KR148950 }\end{array}$ \\
\hline 13. Te-Tconf & T. evanescens & $\begin{array}{l}\text { Guangdong, China } \\
23^{\circ} 4^{\prime} 48^{\prime \prime} \mathrm{N}, 113^{\circ} 8^{\prime} 24^{\prime \prime} \mathrm{E}\end{array}$ & O. furnacalis & $\begin{array}{r}546 \\
\text { KR148951 }\end{array}$ \\
\hline 14. Te-GD & T. evanescens & $\begin{array}{l}\text { Guangdong, China } \\
23^{\circ} 4^{\prime} 48^{\prime \prime} \mathrm{N}, 113^{\circ} 8^{\prime} 24^{\prime \prime} \mathrm{E}\end{array}$ & O. furnacalis & $\begin{array}{r}544 \\
\text { KR148952 }\end{array}$ \\
\hline 15. To-HBZ & T. ostriniae & $\begin{array}{l}\text { Hebianzai, Dehong, China } \\
24^{\circ} 16^{\prime} 57^{\prime \prime} \mathrm{N}, 104^{\circ} 25^{\prime} 21^{\prime \prime} \mathrm{E}\end{array}$ & C. cephalonica & $\begin{array}{r}566 \\
\text { KR148945 }\end{array}$ \\
\hline 16. To-MZ & T. ostriniae & $\begin{array}{l}\text { Mangzai, Dehong, China } \\
24^{\circ} 0^{\prime} 16^{\prime \prime} \mathrm{N}, 101^{\circ} 6^{\prime} 26^{\prime \prime} \mathrm{E}\end{array}$ & C. cephalonica & $\begin{array}{r}566 \\
\text { KR148945 }\end{array}$ \\
\hline 17. To-HS & T. ostriniae & $\begin{array}{l}\text { Hengsui, China } \\
37^{\circ} 32^{\prime} 14^{\prime \prime} \mathrm{N}, 115^{\circ} 28^{\prime} 59^{\prime \prime} \mathrm{E}\end{array}$ & C. cephalonica & $\begin{array}{r}566 \\
\text { KR148946 }\end{array}$ \\
\hline 18. Tem-Tcac & T. embryophagum & $\begin{array}{l}\text { Husa, Dehong, China } \\
24^{\circ} 27^{\prime} 48^{\prime \prime} \mathrm{N}, 97^{\circ} 53^{\prime} 24^{\prime \prime} \mathrm{E}\end{array}$ & C. cephalonica & $\begin{array}{r}587 \\
\text { KR148953 }\end{array}$ \\
\hline 19. Td-NJ & T. dendrolimi & $\begin{array}{l}\text { Nanjing, China } \\
32^{\circ} 3^{\prime} 0^{\prime \prime} \mathrm{N}, 118^{\circ} 46^{\prime} 60^{\prime \prime} \mathrm{E}\end{array}$ & Cnaphalocrocis medinalis & $\begin{array}{r}520 \\
\text { KR148954 }\end{array}$ \\
\hline 20. TJ-GD & T. japonicum & $\begin{array}{l}\text { Guangdong, China } \\
23^{\circ} 4^{\prime} 48^{\prime \prime} \mathrm{N}, 113^{\circ} 8^{\prime} 24^{\prime \prime} \mathrm{E}\end{array}$ & C. suppressalis & $\begin{array}{r}432 \\
\text { KR148955 }\end{array}$ \\
\hline 21. Tj-HS & T. japonicum & $\begin{array}{l}\text { Husa, Dehong, China } \\
24^{\circ} 27^{\prime} 48^{\prime \prime} \mathrm{N}, 97^{\circ} 53^{\prime} 24^{\prime \prime} \mathrm{E}\end{array}$ & S. incertulas & $\begin{array}{r}432 \\
\text { KR148955 }\end{array}$ \\
\hline
\end{tabular}

$72{ }^{\circ} \mathrm{C}$ for $30 \mathrm{~s}$. This was followed by a final extension step at $72^{\circ} \mathrm{C}$ for $7 \mathrm{~min}$. Each reaction was run in a volume of $30 \mu \mathrm{L}$, containing $3 \mu \mathrm{L}(10 \times)$ Taq assay buffer, $300 \mu \mathrm{M}$ dNTP, $0.4 \mu \mathrm{M}$ of each primer, $1 \mathrm{U}$ of Taq DNA polymerase $(\mathrm{TaKaRa}$ Biotechnology, Dalian, China), and 50-100 ng genomic DNA.

The primer used to amplify the wsp fragment from Trichogramma samples was that described by Braig et al. (1998). We also used two conserved Wolbachia genes, fbpA and coxA, to characterize Wolbachia strain for Trichogramma samples, which were amplified based on the methods of Baldo et al. (2006). The PCR primers were designed also according to Baldo et al. (2006). The PCR reaction conditions and the 
Table 2. Information of wsp gene for constructing the phylogenic tree of Wolbachia strains in Fig 1.

\begin{tabular}{|c|c|c|c|}
\hline Group & Wolbachia host species & $\begin{array}{l}\text { Wolbachia } \\
\text { strain }\end{array}$ & $\begin{array}{l}\text { GenBank } \\
\text { Acc. no. }\end{array}$ \\
\hline \multicolumn{4}{|c|}{ Supergroup A } \\
\hline $\mathrm{Ha}$ & Drosophila sechella & $w \mathrm{Ha}$ & AF020073 \\
\hline $\mathrm{Ha}$ & Cadra cautella & wCauA & AF020075 \\
\hline Aus & Glossina austeni & wAus & AF020077 \\
\hline Kue & Trichogramma ourarachae & wBou & AF071913 \\
\hline Kue & Trichogramma evanescens & wEvaB & AY390280 \\
\hline Kue & Trichogramma kaykai & wKayA & AF071912 \\
\hline Mel & Drosophila simulans & wCof & AF020067 \\
\hline Mel & Amitus fuscipennis & wFus & AF071909 \\
\hline Mel & Drosophila melanogaster & wMel & AF020063 \\
\hline Dro & Trichogramma drosophilae & wDro & AF071910 \\
\hline Eva & Trichogramma evanescens & wEvaA & AY390279 \\
\hline Pap & Phlebotomus papatasi & wPap & AF020082 \\
\hline Uni & Muscidifurax uniraptor & $w U n i$ & AF020071 \\
\hline Mors & Nasonia vitripennis & WitA & AF020081 \\
\hline \multicolumn{4}{|c|}{ Supergroup B } \\
\hline Ori & Leptopilina australis & wAus & AF071920 \\
\hline Ori & Cadra cautella & wCauB & AF020076 \\
\hline Ori & Spalangia fuscipes & $w F u$ & AF071921 \\
\hline Con & Trichogramma bedeguaris & $w B e d$ & AF071915 \\
\hline Dei & Trichogramma deion & $w D e i$ & AF020084 \\
\hline Vul & Armadillidium vulgare & $w$ Vul & AF071917 \\
\hline Pip & Trichogramma chilonis & wChi & AY311486 \\
\hline Pip & Drosophila simulans & wMa & AF020069 \\
\hline \multirow[t]{2}{*}{ Pip } & Culex pipiens & wPip & AF020061 \\
\hline & Spodoptera exigua & $w E x i B$ & EU332344 \\
\hline Pip & Ostrinia furnacalis & $w F u r B$ & EU294312 \\
\hline Kay & Trichogramma kaykai & wKayB & AF071924 \\
\hline Kay & Trichogramma nubilale & wNub & AF071926 \\
\hline \multicolumn{4}{|c|}{ Supergroup D } \\
\hline \multicolumn{4}{|c|}{ Supergroup F } \\
\hline & Cimex lectularius & & DQ842459 \\
\hline
\end{tabular}

thermal cycling protocol were identical to those described above.

After purified with PCR Cleanup Kit (Axygen, USA), the PCR products were directly sequenced on an Automated DNA Sequencer (ABIPRISMTM 3730XL, APPLIEDBIOSYSTEMS, INC. Foster City, CA). All sequences were aligned using CLUSTAL_X (Thompson et al. 1997) and rechecked by eye to verify for accuracy.

\subsection{Phylogenetic analysis}

The wsp, coxA, and fbpA sequences of Wolbachia from the different Trichogramma populations were first blasted in NCBI, then analyzed and aligned with Clustal X1.83 (www.clustal.org). Some reference sequences of Wolbachia wsp, $\operatorname{cox} \mathrm{A}$, and $f b p \mathrm{~A}$ sequences of other species were downloaded from GenBank for the phylogenetic analysis of Wolbachia (Tables 2 and 3). In order to verify the consistency of the tree, phylogenetic trees were constructed using two methods, neighbor joining $(\mathrm{NJ})$ and maximum parsimony (MP) (Mega 4.0 software, MEGA, www.megasoftware.net). Bootstrap analysis was done with 1,000 replications, and bootstrap values were calculated using a 50\% majority rule. Two reference sequences belonging to the Wolbachia $\mathrm{D}$ and $\mathrm{F}$ supergroups were used as the outgroups in the phylogenetic trees of wsp, coxA, and $f b p \mathrm{~A}$; Brugia malayi (Brug, 1927) (wsp JX506736, 
Table 3. Host species, supergroups and GenBank accession numbers of coxA and fbpA genes for constructing the phylogenic tree (Fig. 2) of Wolbachia strains.

\begin{tabular}{|c|c|c|c|}
\hline $\begin{array}{l}\text { Host species } \\
\text { or subspecies }\end{array}$ & Supergroup & $\begin{array}{c}\operatorname{coxA} \\
\text { Accession no. }\end{array}$ & $\begin{array}{c}\text { fbpA } \\
\text { Accession no. }\end{array}$ \\
\hline Brugia malayi & $\mathrm{D}$ & DQ842273 & DQ842347 \\
\hline Cimex lectularius & $\mathrm{F}$ & DQ842275 & DQ842349 \\
\hline Acromis sparsa & A & DQ842271 & DQ842345 \\
\hline Aedes albopictus & A & DQ842268 & DQ842342 \\
\hline Camponotus pennsylvanicus & A & DQ842276 & DQ842350 \\
\hline Drosophila bifasciata & A & DQ842279 & DQ842353 \\
\hline Drosophila innubila & $A$ & DQ842280 & DQ842354 \\
\hline Drosophila melanogaster & A & DQ842304 & DQ842378 \\
\hline Drosophila neotestacea & $A$ & DQ842281 & EU126408 \\
\hline Drosophila orientacea & A & DQ842282 & EU126398 \\
\hline Drosophila recens & A & DQ842283 & DQ842357 \\
\hline Ephestia kuehniella & $A$ & DQ842289 & DQ842363 \\
\hline Incisitermes snyderi & A & DQ842292 & DQ842366 \\
\hline Muscidifurax uniraptor & A & DQ842293 & DQ842367 \\
\hline Nasonia giraulti & A & DQ842294 & DQ842368 \\
\hline Nasonia longicornis & A & DQ842295 & DQ842369 \\
\hline Nasonia vitripennis & A & FJ390240 & DQ842370 \\
\hline Solenopsis invicta & A & DQ842300 & DQ842374 \\
\hline Acraea encedon & B & DQ842269 & DQ842343 \\
\hline Acraea eponina & B & DQ842270 & DQ842344 \\
\hline Armadillidium vulgare & B & FJ390241 & EF451552 \\
\hline Chelymorpha alternans & B & DQ842274 & DQ842348 \\
\hline Culex pipiens pipiens & B & DQ842277 & DQ842351 \\
\hline Culex pipiens quinquefasciatus & B & DQ842278 & DQ842352 \\
\hline Drosophila simulans & B & KF987018 & KF987033 \\
\hline Encarsia formosa & B & DQ842288 & DQ842362 \\
\hline Gryllus firmus & B & DQ842291 & DQ842365 \\
\hline Nasonia vitripennis & B & DQ842297 & DQ842371 \\
\hline Ostrinia scapulalis & B & DQ842298 & DQ842372 \\
\hline Protocalliphora sialia & B & DQ842299 & DQ842373 \\
\hline Teleogryllus taiwanemma & B & DQ842303 & DQ842377 \\
\hline Tribolium confusum & B & DQ842301 & DQ842375 \\
\hline Trichogramma deion & B & DQ842302 & DQ842376 \\
\hline
\end{tabular}

coxA DQ842273, fbpA DQ842347) and Cimex lectularius (Latreille, 1802) (wsp DQ842459, coxA DQ842275, fbpA DQ842349).

\section{Results}

\subsection{Trichogramma identification and distribution}

The ITS 2 sequences that were obtained from each population were compared with the identified ITS2 sequences of rDNA from GenBank to confirm the identification of Trichogramma species (Table 4). Six Trichogramma species were identi- fied: T. chilonis (Ishii, 1941) (seven populations), T. evanescens (Westwood, 1833) (seven populations), T. ostriniae (Pang \& Chen, 1974) (three populations), T. embryophagum (Hartig, 1838) (one population), T. dendrolimi (Matsumura, 1926) (one population) and T. japonicum (Ashmead, 1904) (two populations). The ITS2 sequences obtained from each species were (97$100 \%$ Max Ident score in BLAST) similar to those present in GenBank. In this study, a total of eleven ITS2 sequences were deposited in GenBank (accession numbers KR148945-KR148955) (Table 1), and these sequences were complete ITS2 sequences plus flanking sequences of $5.8 \mathrm{~S}$ and $28 \mathrm{~S}$. Although these sequences display 
Table 4. Sequences used from GenBank for comparison of the Trichogramma species in this study.

\begin{tabular}{|c|c|c|c|c|}
\hline $\begin{array}{l}\text { Sample no. } \\
\text { and spp. }\end{array}$ & Sequence & Base pairs & $\begin{array}{l}\text { Accession no. } \\
\text { similarity (\%) }\end{array}$ & Sequence \\
\hline 1. T. chilonis & partial ITS-2 & 1,155 & AY167415 & 99 \\
\hline 2. T. chilonis & partial ITS-2 & 1,158 & AY167418 & 99 \\
\hline 3. T. chilonis & Complete ITS-2 & 560 & DQ088055 & 99 \\
\hline 4. T. chilonis & Complete ITS-2 & 538 & GU562445 & 99 \\
\hline 5. T. evanescens & Complete ITS-2 & 559 & DQ088059 & 99 \\
\hline 6. T. evanescens & Complete ITS-2 & 546 & FJ436332 & 99 \\
\hline 7. T. evanescens & Complete ITS-2 & 546 & JN315373 & 99 \\
\hline 8. T. evanescens & Complete ITS-2 & 546 & JN315380 & 99 \\
\hline 9. T. ostriniae & Complete ITS-2 & 446 & AY244463 & 98 \\
\hline 10. T. ostriniae & Complete ITS-2 & 447 & AY518695 & 99 \\
\hline 11. T. ostriniae & Complete ITS-2 & 491 & GQ324625 & 98 \\
\hline 12. T. embryophagum & Complete ITS-2 & 479 & AF453562 & 100 \\
\hline 13. T. embryophagum & Complete ITS-2 & 474 & AY244465 & 100 \\
\hline 14. T. embryophagum & Complete ITS-2 & 593 & DQ344044 & 97 \\
\hline 15. T. embryophagum & Complete ITS-2 & 530 & JF920430 & 97 \\
\hline 16. T. dendrolimi & partial ITS-2 & 510 & AB094398 & 98 \\
\hline 17. T. dendrolimi & Complete ITS-2 & 412 & AF453555 & 99 \\
\hline 18. T. dendrolimi & Complete ITS-2 & 540 & AF517576 & 98 \\
\hline 19. T. dendrolimi & Complete ITS-2 & 465 & DQ344045 & 97 \\
\hline 20. T. japonicum & Complete ITS-2 & 578 & DQ471294 & 98 \\
\hline 21. T. japonicum & partial ITS-2 & 436 & FN822756 & 98 \\
\hline 22. T. japonicum & partial ITS-2 & 438 & FN822758 & 98 \\
\hline 23. T. japonicum & partial ITS-2 & 436 & FN822759 & 98 \\
\hline
\end{tabular}

significant interspecies differences, they showed low intraspecific variability in length (2-10 bases).

The comparison showed that $T$. chilonis was found from seven populations with three different sequences, Tc-CJ and Tc-WLP (KR148947); Tc-Lo, Tc-NB, Tc-MM, Tc-TW (KR148948); Tc-HS (KR148949) (Table 1). The three sequences had only three mutation sites, and the sequences were closely similar (99\%) to T. chilonis in GenBank accession numbers AY167415, AY167418, DQ088055 and GU562445 (Table 4).

The T. evanescens specimens from seven populations had three different sequences: Te-HS, Te-BJ, Te-CQ, Te-K1 and Te-K2 (KR148950); Te-Tconf (KR148951); Te-GD (KR148952) (Table 1). The three sequences had 10 mutation sites, and the sequences were closely similar $(99 \%)$ to T. evanescens in GenBank accession numbers DQ088059, FJ436332, JN315373 and JN315380 (Table 4).
The T. ostriniae specimens from three populations had two different sequences: To-HBZ and To-MZ (KR148945); To-HS (KR148946), which had two mutation sites (Table 1). The two sequences were closely similar (98-99\%) to $T$. ostriniae in GenBank accession numbers AY244463, AY518695 and GQ324625 (Table 4).

The sequence of $T$. embryophagum, TemTcac (KR148953), was closely similar (97$100 \%$ ) to GenBank accession numbers AF453562, AY244465, DQ344044 and JF920430 (Table 4).

The sequence of $T$. dendrolimi (Td-NJ, KR148954) was closely similar (97-99\%) to that of $T$. dendrolimi available in GenBank (AB094398, AF453555, AF517576 and DQ344045) (Table 4).

The sequence of $T$. japonicum (Tj-GD and $\mathrm{Tj}-$ HS KR148955) was closely similar (98\%) to that of T. japonicum available in GenBank (DQ471294, FN822756, FN822758 and FN822759) (Table 4). 


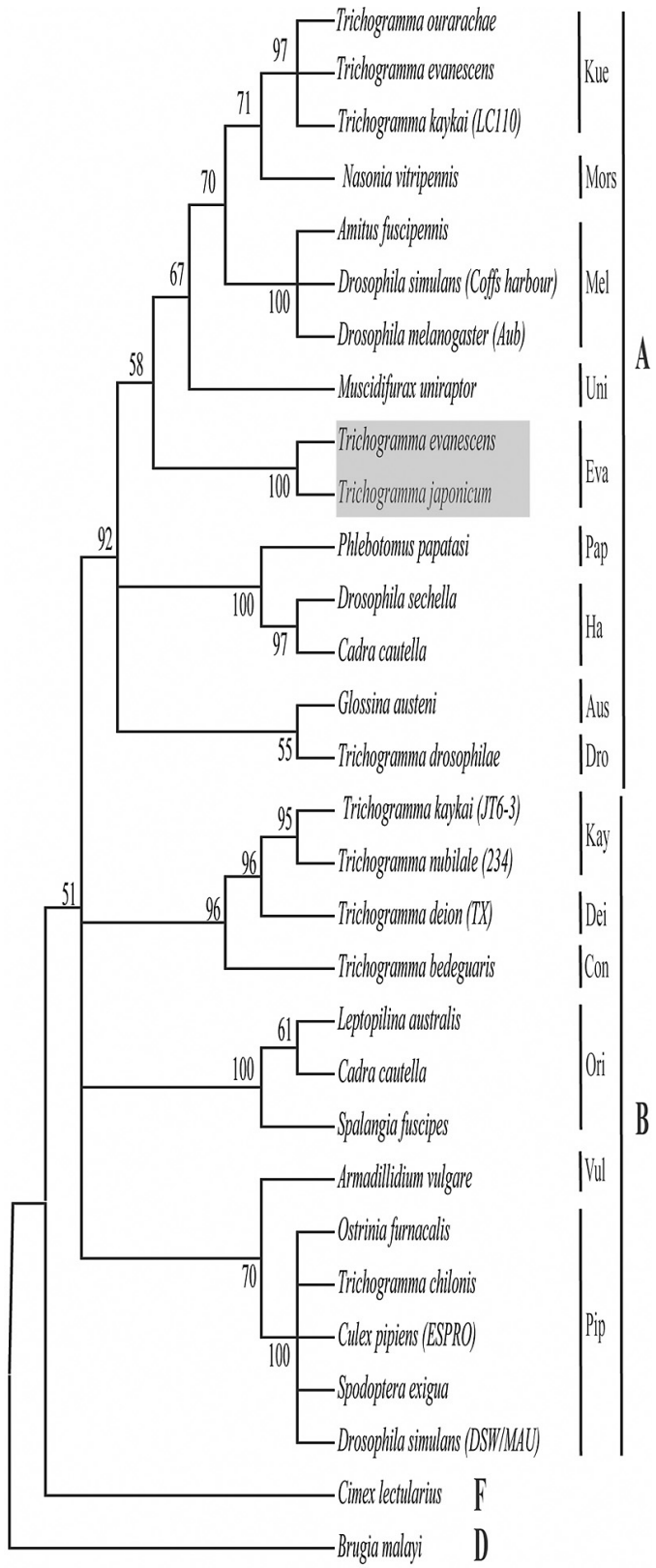

Fig. 1. Phylogenetic neighbor joining tree of Wolbachia based on wsp sequences. For information of wsp gene, see Table 2. Sequences of Brugia malayi and Cimex lectularius were used as outgroups. Names of host species and their related groups are listed on the right side of the figure. Supergroups of Wolbachia are shown as uppercase letters. The infected strain of Trichogramma japonicum clustered together with that of Trichogramma evanescens, which were the strain Eva. They are highlighted by shaded area. Bootstrap values $>50 \%$ are shown above branches.

\subsection{Identification of the associated Wolbachia strain}

The detection of Wolbachia was performed for Trichogramma species from 21 sites. The infection existed in only five populations, which were Tc-TW, Te-BJ, Te-K1, Tem-Tcac and Tj-GD, and all tested individuals of these five populations were infected. Furthermore, all of the five populations were found to have identical sequences of the wsp, coxA and $f b p \mathrm{~A}$ genes. As these five populations were infected with the same Wolbachia strain, only one of them (Trichogramma japonicum) was used for the phylogenetic analysis based on wsp, coxA and fbpA genes.

The phylogenetic analysis was performed for the Trichogramma Wolbachia wsp sequences and 29 reference sequences. The tree has two major branches, corresponding to supergroups A and B (Fig. 1). The wsp sequence in Trichogramma samples shared $100 \%$ identity with the sequences from T. evanescens (AY390279). This Wolbachia strain was defined in the strain $w E v a \mathrm{~A}$ in the group of Eva of the supergroup A (Fig. 1). The phylogenetic tree for the concatenated sequences of Wolbachia coxA and fbpA is shown in Fig. 2. Similar to the wsp tree, the concatenated sequences were first clustered into supergroup A branch. The concatenated sequences were clustered into a subclade with Aedes albopictus (Skuse, 1894) (coxA DQ842268 and fbpA DQ842342), sharing 99\% identity (Fig. 2). As the topologies of the trees inferred from neighbor joining and maximum parsimony were similar based on wsp and concatenated coxA and $f b p \mathrm{~A}$ sequences, we only displayed the trees constructed by neighbor joining (Figs 1 and 2). The sequences for the wsp, fbpA and coxA genes were deposited in GenBank with the accession numbers KR906068, KR906069 and KR906070.

\section{Discussion}

ITS2 provides an excellent method for separating closely related species of Trichogramma. The main advantage of the DNA identification system over the morphological system is that it is fast and requires few specialized skills, and can work well on the dried or $100 \%$ alcohol stored specimen(s). 


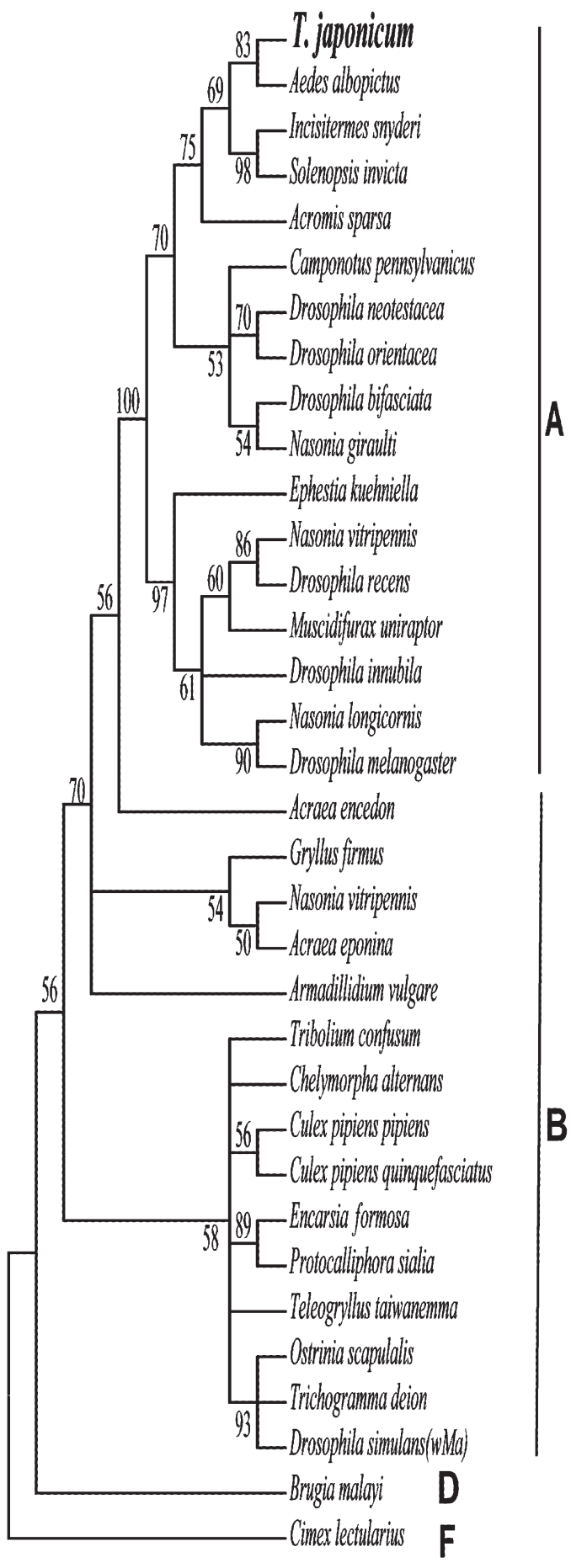

More and more resources of Trichogramma ITS2 genes are becoming publicly available from NCBI database, which provides a rich source of
Fig. 2. Phylogenetic neighbor joining tree of Wolbachia based on concatenated sequences of coxA and fbpA. For information of coxA and fbpA genes, see Table 3. Sequences of Brugia malayi and Cimex lectularius were used as outgroups. Names of host species and their related groups are listed on the right side of the figure. Supergroups of Wolbachia are shown as uppercase letters. Population of Trichogramma japonicum is highlighted by boldface in the figure. Bootstrap values $>50 \%$ are shown above branches.

information for the identification of Trichogramma species.

In this study, the sequences of the tested Trichogramma samples were blasted in NCBI and the species with $98-100 \%$ identity were identified as the same species. Finally, the identification results of molecular methods and morphological characters were identical. Therefore, it can be deduced that the results of the molecular identification based on ITS2 genes are reliable.

The phylogeny of Wolbachia has been studied extensively based on different gene sequences (Rousset et al. 1992, Braig et al. 1998). As the extensive recombination and strong diversifying selection affect the wsp gene, it is an unreliable tool for the characterization of Wolbachia (Werren \& Bartos 2001, Baldo et al. 2002, Jiggins et al. 2002, Baldo et al. 2005). Therefore, another two Wolbachia genes, coxA and $f b p \mathrm{~A}$, were also applied.

In this study, Wolbachia infection was found only in five populations of Trichogramma from 21 sites. The phylogenetic analysis of the Wolbachia wsp sequences revealed that the Wolbachia strain belonged to the strain $w E v a \mathrm{~A}$ in the group of Eva of the supergroup A. The phylogenetic tree of also the concatenated coxA and $f b p \mathrm{~A}$ revealed that the Wolbachia strain of Trichogramma was defined as supergroup A, and it was closely, with $83 \%$ identity, related to the Wolbachia of Aedes albopictus.

In a recent study using the wsp gene and five genes in multilocus sequence typing (MLST) (Poorjavad et al. 2012), only two populations of Trichogramma brassicae (Bezdenko, 1968) from 34 tested Trichogramma populations were infected by Wolbachia. The two populations were 
infected with the same Wolbachia strain, which was defined in supergroup B in that study.

Although the Wolbachia infection rates were low in both our current study and in that of Poorjavad et al. (2012), the Wolbachia strains were different. The two T. brassicae populations were from Iran, i.e. Western Asia, whereas the five infected populations in our study were from East Asia and South-East Asia. It is thus possible that the Trichogramma populations in Western Asia are infected with different Wolbachia strains than those in East Asia and South-East Asia.

The molecular identification and Wolbachia infection test for the Trichogramma species from 21 populations can provide an important aid for biological control programs using Trichogramma spp.

Acknowledgments. We thank two anonymous reviewers for their valuable comments to improve the manuscript. We also thank Prof. Hongying Hu from Xinjiang University for Trichogramma morphological identification. This research was funded by the National Natural Science Foundation of China (31370439) and a EuropeAid project (DCIFood/2010/230-238).

\section{References}

Baldo, L., Bartos, J. D., Werren, J. H., Bazzocchi, C., Casiraghi, M. \& Panelli, S. 2002: Different rates of nucleotide substitutions in Wolbachia endosymbionts of arthropods and nematodes: arms race or host shifts? Experimental parasitology 44: 179-187.

Baldo, L., Dunning Hotopp, J. C., Jolley, K. A., Bordenstein, S. R., Biber, S. A., Choudhury, R. R., Hayashi, C., Maiden, M. C. J., Tettelin, H. \& Werren, J. H. 2006: Multilocus sequence typing system for the endosymbiont Wolbachia pipientis. - Applied and Environmental Microbiology 72: 7098-7110.

Baldo, L., Lo, N. \& Werren, J. H. 2005: Mosaic nature of the Wolbachia surface protein. - Journal of Bacteriology 187: 5406-5418.

Braig, H. R., Zhou, W., Dobson, S. L. \& O’Neill, S. L. 1998: Cloning and characterization of a gene encoding the major surface protein of the bacterial endosymbiont Wolbachia pipientis. - Journal of Bacteriology 180: 2373-2378.

Grissel, E. E. \& Schauff, M. E. 1990: A handbook of the families of Nearctic Chalcidoidea (Hymenoptera). Proceedings of the Entomological Society of Washington. 85 pp.

Gross, B. L. \& Zhao, Z. J. 2014: Archaeological and genetic insights into the origins of domesticated rice. Proceedings of the National Academy of Sciences 111: 6190-6197.
Guo, Z., Ruan, C. C., Zang, L. S., Zhang, F. \& Jin, F. Y. 2011: The new record of Trichogramma japonicum ashmead, an egg parasitoid of Chilo suppressalis (Walker) in Jilin, China. - Biological Control 27: 276-279.

Harris, H. L., Braig, H. R. \& Journal, A. 2003: Sperm chromatin remodelling and Wolbachia-induced cytoplasmic incompatibility in Drosophila. — Biochemistry and Cell Biology 81: 229-240.

Hassan, S. A. 1994: Strategies to select Trichogramma species for use in biological control. - In: Wajnberg, E. \& Hassan, S. A. (eds.), Biological control with egg parasitoids: 55-71. CAB International, Wallingford (UK). 304 pp.

Horjus, M. \& Stouthamer, R. 1995: Does infection with thelytoky causing Wolbachia in the pre-adult and adult life stages influence the adult fecundity of Trichogramma deion and Muscidifurax uniraptor? - Proceedings Experimental and Applied Entomology 6: 35-40.

Jiggins, F. M., Hurst, G. D. D. \& Yang, Z. H. 2002: Hostsymbiont conflicts: positive selection on an outer membrane protein of parasitic but not mutualistic Rickettsiaceae. - Molecular Biology and Evolution 19: 1341-1349.

Ko, K., Liu, Y. D., Hou, M. L., Babendreier, D., Zhang, F. \& Song, K. 2014: Evaluation for potential Trichogramma (Hymenoptera: Trichogrammatidae) strains for control of the Striped Stem Borer (Lepidoptera: Crambidae) in the Greater Mekong Subregion. Journal of Economic Entomology 107: 955-963.

Kumar, A. G., Jalali, S. K., Venkatesan, T., Stouthamer, R., Niranjana, P. \& Lalitha, Y. 2009: Internal transcribed spacer-2 restriction fragment length polymorphism (ITS-2-RFLP) tool to differentiate some exotic and indigenous Trichogrammatid egg parasitoids in India. - Biological Control 49: 207-213.

Nasir, M. F., Hagedorn, G., Büttner, C., Reichmuth, C. \& Schöller, M. 2013: Molecular identification of Trichogramma species from Pakistan, using ITS-2 region of rDNA. - Biological Control 58: 483-491.

Pino, M. D., Rugman-Jones, P., Herna'ndez-Sua'rez, E., Polaszek, A. \& Stouthamer, R. 2013: Rapid molecular identification of five species of Trichogramma occurring in the Canary Islands with notes on their distribution in banana groves. - Biological Control 58: 515524.

Pinto, J. D., Velten, R. K., Platner, G. R. \& Oatman, E. R. 1989: Phenotypic plasticity and taxonomic characters in Trichogramma (Hymenoptera: Trichogrammatidae). - Annals of the Entomological Society of America 82: 414-425.

Pinto, J. H. \& Stouthamer, R. 1994: Systematics of the Trichogrammatidae with emphasis on Trichogramma. In: Wajnberg, E. \& Hassan, S. A. (eds), Biological Control with Egg Parasitoids: 1-35. CAB International, Wallingford (UK). 304 pp.

Poorjavad, N., Goldansaz, S. H., Machtelinckx, T., Tirry, L., Stouthamer, R. \& Van Leeuwen, T. 2012: Iranian Trichogramma: ITS2 DNA characterization and natu- 
ral Wolbachia infection. - Biological Control 57: 361-374.

Rousset, F., Bouchon, D., Pintureau, B., Juchault, P. \& Solignac, M. 1992: Wolbachia endosymbionts responsible for various alterations of sexuality in arthropods. — Proceedings of the Royal Society B Biological Sciences 250: 91-98.

Silva, I. M. M. S., Honda, J., van Kan, F., Hu, J. G., Neto, L., Pintureau, B. \& Stouthamer, R. 1999: Molecular differentiation of five Trichogramma species occurring in Portugal. - Biological Control 16: 177-184.

Stouthamer, R., Hu, J. G., van Kan, F. J. P. M., Platner, G. R. \& Pinto, J. D. 1999: The utility of internally transcribed spacer 2 DNA sequences of the nuclear ribosomal gene for distinguishing sibling species of Trichogramma. - Biological Control 43: 421-440.

Stouthamer, R. \& Kazmer, D. J. 1994: Cytogenetics of mi- crobe-associated parthenogenesis and its consequences for gene flow in Trichogramma wasps. - Heredity 73 : 317-327.

Sumer, F., Tuncbilek, A. S., Oztemiz, S., Pintureau, B., Rugman-Jones, P. \& Stouthamer, R. 2009: A molecular key to the common species of Trichogramma of the Mediterranean region. - BioControl 54: 617-624.

Thompson, J. D., Gibson, T. J., Plewniak, F., Jeanmougin, F. \& Higgins, D. G. 1997: The CLUSTAL X windows interface: flexible strategies for multiple sequence alignment aided by quality analysis tools. — Nucleic Acids Research 25: 4876-4882.

Werren, J. H. 1997: Biology of Wolbachia. — Annual Review of Entomology 42: 587-609.

Werren, J. H. \& Bartos, J. D. 2001: Recombination in Wolbachia. - Current Biology 11: 431-435. 